\title{
TRATAMENTO DAS FORMAS SEVERAS DE MIASTENIA PELO ACTH POR VIA INTRAVENOSA
}

\author{
José Lamartine de Assis *
}

A miastenia é caracterizada por fatigabilidade anormalmente rápida dos músculos sob ação dos contrôles voluntário e automático, seguida de volta da fôrça, pelo menos em parte, depois de período de repouso. Os conhecimentos básicos sôbre a fisiologia e fisiopatologia devem-se a Loewi ${ }^{47}$ e Dale 19, 20, que mostraram, em 1932, a importância da acetilcolina na transmissão dos impulsos nervosos. A partir de 1935 as técnicas eletromiográficas ${ }^{46}$ e ergográficas ${ }^{8}$ foram utilizadas para esclarecer $o$ bloqueio da junção neuromuscular, quer no que concerne às suas caracteristicas ${ }^{7,35}$, quer quanto à sua origem e mecanismo $28,36,40,59$.

Em 1934, com Mary Walker ${ }^{97,98}$ foi iniciada a era moderna do tratamento da miastenia, primeiro com a eserina (fisostigmina) e, depois, com a prostigmina, muito menos tóxica e melhor tolerada. Desde então o prognóstico se modificou e numerosos trabalhos confirmaram a ação anticolinesterásica da Prostigmina; esta ação é de tal ordem que Viets e Schwab ${ }^{96}$ salientaram, em 1935, o valor da droga como teste para o diagnóstico da doença.

Em 1939 Blalock e col. ${ }^{6}$ mostraram que a remoção cirúrgica de tumor do timo era seguida de remissão dos sintomas miastênicos. Keynes ${ }^{43}$, Simpson ${ }^{74}$ e Eaton e Clagett ${ }^{25,26}$ trouxeram importantes contribuições para a avaliação e indicação da timectomia.

No decênio 1940-1950 quatro compostos fosforados foram utilizados por terem mostrado potente ação anticolinesterásica: o di-isopropilfluorofosfato (DFP) ${ }^{17}$, o tetraetilpirofosfato (TEPP) ${ }^{31}$, a octametilpirofosforamida (OMPA) ${ }^{62,72}$ e o hexaetiltetrafosfato (HETP) ${ }^{100}$; infelizmente os limites entre os efeitos terapêuticos e os tóxicos são tão estreitos que tornam perigoso o emprêgo dêstes compostos ${ }^{55}$. A partir de 1948 foram feitas as primeiras tentativas de tratamento com os hormônios adrenocorticotrópicos e corticosteróides; Soffer ${ }^{77}$, Millikan e Eaton ${ }^{49}$, Schlezinger ${ }^{67}$, Torda e Wolff ${ }^{93}$ e Grob e Harvey ${ }^{32}$ obtiveram algum sucesso com o emprêgo do ACTH e da cortisona.

Neste último decênio apareceram novas drogas de potente ação anticolinesterásica, de fácil manuseio e com poucos efeitos tóxicos e/ou cola-

Trabalho da Clínica Neurológica da Fac. Med. da Univ. de São Paulo (Prof. A. Tolosa), apresentado à Academia de Medicina de São Paulo.

* Livre-Docente. 
terais: salientam-se o brometo de mestinon ou Piridostigmina 80, 103 (dimetilcarbamato de 3-hidroxi-1-metilpirídio), o Mytelaze ou cloreto de mysuran (WIN-8077) ou Ambenoniun 69, 99, o Tensilon 100, 102 (cloreto de 3-hidroxifenildimetilamônio), êste último ușado por Osserman e col.54,56 como teste para o diagnóstico rápido de miastenia. Estão em fase experimental as drogas $\mathrm{BC}$, isto é, as formas bis de Prostigmina e do Mestinon: $\mathrm{BC}-40^{58}$ (bis-Prostigmina) e BC-5158 (bis-Mestinon).

Finalmente, têm sido ensaiadas drogas capazes de reativar uma enzima inibidora da colinesterase (oximas ${ }^{33}, 34$ ), dentre as quais salientam-se duas: a PAM (piridina-2-aldoxima) e a DAM (diacetil-monoxima), que poderão resolver melhor o problema terapêutico das crises colinérgicas, anulando os efeitos tóxicos dos compostos amoniacais quaternários (Prostigmina, Mestinon, Mytelaze, BC-40 e BC-51).

Bases bioquimicas do tratumento da miastenia pelo ACTH - A acetilcolina é um mediador químico de grande importância no tecido nervoso, matendo relações estreitas com a condução nervosa, atuando sôbre os fe-

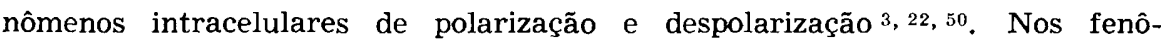
menos metabólicos da acetilcolina intervêm duas enzimas importantes - a colinacetilase e a colinesterase ${ }^{45,61}$ - a primeira esterificante e a segunda hidrolisante.

O metabolismo da acetilcolina apresenta interrelações importantes com outros sistemas metabólicos que fornecem energia, pois sua síntese é endoenergética. Duas são as substâncias básicas da síntese dêsse produto: o ácido acético e a colina. A colina deriva de certos aminoácidos como a glicola que, por fenômenos de condensação com ácido fórmico em presença de certas enzimas, dá a serina que, descarboxilada, produz a etanolamina, a qual, metilada pela metionina e fermentos ainda não isolados, dá origem à colina. O ácido acético entra num sistema enzimático importante: pela ação do ATP (trifosfato de adenosina) reage com a coenzima A (CoA), dando o acetil-coenzima A ou ácido acético ativado; êste, em presença da colinacetilase e dos iontes magnésio, potássio e cálcio, reage com a colina. produzindo a acetilcolina.
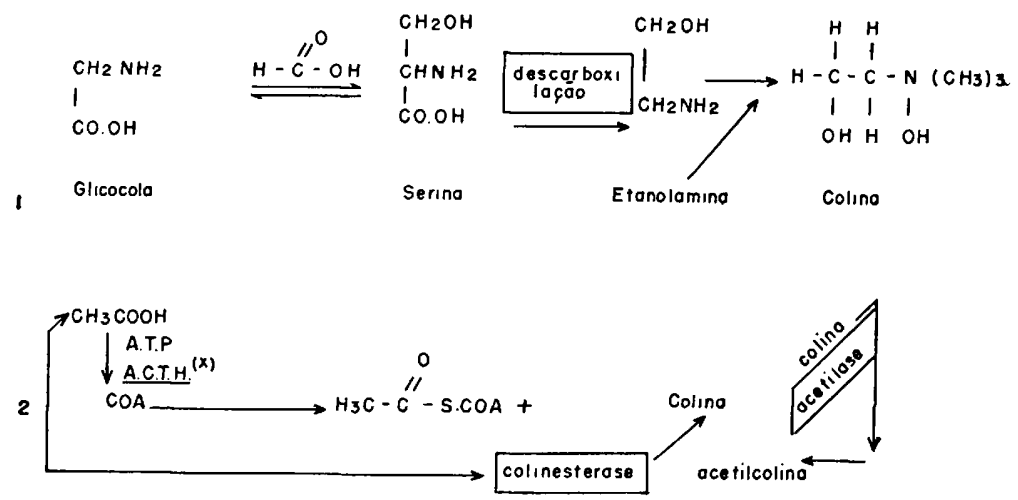
Parece que o ACTH tem ação na sintese da acetilcolina pela ativação da colinacetilase ${ }^{87,88}$. Uma vez formada, a acetilcolina sofre a ação de um fermento hidrolisante, a colinesterase, originando ácido acético e colina.

Bases fisiopatológicas do tratamento da miastenia pelo $A C T H-\mathrm{O}$ mecanismo exato dos efeitos benéficos do $\mathrm{ACTH}$ na miastenia ainda não é conhecido. Com base nos trabalhos de Torda e Wolff 83,89 , a causa imediata da doença seria a diminuição da síntese da acetilcolina, pois o ACTH aumenta a sintese da acetilcolina in vivo e in vitro $83,90,94$; parece que o ACTH atua ativando a colinacetilase ${ }^{88}$. Está provado, também, que o ACTH é capaz de modificar a transmissão neuromuscular; nos animais hipofisectomizados ${ }^{92,94}$, a capacidade de contração muscular diminui, o eletromiograma se altera e se aproxima muito do observado em pacientes com miastenia, há diminuição da amplitude do potencial de ação do músculo, diminuição da síntese da acetilcolina, além de hipertrofia do timo e do tecido linfóide em geral; em tais circunstâncias a administração do ACTH regulariza a função neuromuscular e aumenta a sintese da acetilcolina 39,83, 90,91,94. A patologia demonstra, também, a possível ação do ACTH na contração muscular, pela coexistência de casos de miastenia grave com lesões associadas da hipófise 53,106 .

Também deve ser salientado que o aumento dos órgãos linfóides em geral e do timo em particular, encarados como massas de tecidos hiperfuncionantes, é capaz de diminuir a síntese da acetilcolina. Hoje não se contesta a relação entre timo e miastenia, em que pese o pouco conhecimento sôbre as funções desta glândula e do modo pelo qual ela influi no aparecimento ou na agravação da síndrome miastênica.

A alteração histológica mais constante do timo na miastenia é a hiperplasia linfóide associada ao menor grau de involução do órgão 5, 51,53. O timo cresce até a puberdade quando atinge o seu maior pêso e, depois, involui. Nos pacientes com miastenia não há involução do timo, ou ela é retardada; às vêzes há modificação estrutural no sentidó de hiperplasia ou de tumor (timoma), o que pode coincidir com agravação do quadro miastênico ${ }^{5,51}$. Torda e Wolff 85, 89 mostraram, em animais, que injeçōes de extrato de timo inibem a síntese da acetilcolina; também foi demonstrado que extratos de timo de pacientes com miastenia diminuem de modo sensível a síntese da acetilcolina. Pesquisas recentes 59,104 confirmam a possibilidade do timo elaborar uma substância responsável pelo bloqueio da junção neuromuscular na miastenia. Êstes efeitos inibidores foram observados não só com os extratos de timo como também com os extratos de músculos estriados e de nódulos linfóides $59,85,89,104$ e com o sôro sangüíneo 84 de pacientes miastênicos. Esta ação inibidora atuaria diminuindo a síntese da acetilcolina 85,89 .

Outro fato que precisa ser salientado é que a extrema involução do timo, determinada por infecções sistêmicas agudas e outras afecções ou por fatôres não específicos, tem sido considerada como expressão do "fenômeno stress" 71 no sentido de reação contra a doença. Se na miastenia a involu- 
ção do timo não se processa ou é retardada, isto significa que a reação contra a doença é menor, talvez dependendo, em parte, de insuficiência supra-renal relativa, independente de lesão primária das glândulas supra-renais ${ }^{42,71}$. A involução aguda do timo, que começa algumas horas ou alguns dias após a ação do fator desencadeante, se caracteriza por rápida regressão dos elementos linfóides, especialmente da camada cortical. Fato curioso é que esta involução não ocorre, mesmo em face dos agentes desencadeantes, na falta do tecido cortical supra-renal; nestas condições, tal como acontece nos animais hipofisectomizados ${ }^{92,94}$, vai haver aumento de volume do timo e diminuição da capacidade de contração dos músculos esqueléti$\cos 42,71$. A administração do ACTH promove a involução do timo e do tecido linfóide em geral ${ }^{24,82,91}$ e corrige a insuficiência supra-renal 42, 71, com o que concorre, indiretamente, para aumentar a síntese da acetilcolina 88, 91 .

Bases anátomo-patológicas para o tratamento da miastenia pelo ACTH - Se o sistema nervoso dos pacientes com miastenia grave não apresenta comprometimento que justifique o emprêgo do ACTH em seu tratamento, pois na maioria das vêzes não se encontram lesões neurológicas ${ }^{65}$, as alterações histológicas do timo, dos músculos estriados e do coração fundamentam, em muitos casos, a tentativa terapêtica mediante o emprêgo dêsse hormônio. Como foi referido, a maioria dos miastênicos apresenta hiperplasia do tecido linfóide em geral e do timo em particular. O ACTH promove a redução da massa dêsses tecidos, atuando particularmente sôbre os linfócitos $24,82,91$.

De acôrdo com vários autores ${ }^{53}$, cêrca de $50 \%$ dos pacientes com miastenia apresentam lesões dos músculos estriados; as alterações histológicas vão desde as clássicas "linforragias" até as necroses focais ou difusas, acompanhadas de reação inflamatória aguda ou crônica ", 65. Russell ${ }^{66}$ admite que as "linforragias" e outras lesões dos músculos estriados tenham relação com as alterações do timo, sendo classificadas em três tipos: o tipo 1 se caracteriza por necrose aguda coagulante da fibra muscular precedida de edema, intensa eosinofilia do sarcoplasma e perda dos seus núcleos e da estriação cruzada, pronunciado exsudato inflamatório na fibra e ao seu redor, com macrófagos, linfócitos, células plasmáticas e, às vêzes, predomínio dos polimorfonucleares neutrófilos; o tipo 2, encontrável em todos os casos, compreende as "linforragias", com degeneração e atrofia das fibras musculares; o tipo 3 consiste em alterações focais com edema e eosinofilia do sarcoplasma sem perda de estriação e sem reação inflamatória, havendo atrofia subseqüente da fibra muscular.

Russell considera as lesões dos tipos 1 e 2 como específicas da miastenia grave. Os três tipos de lesões podem ocorrer de modo isolado ou em qualquer combinação, e sua patogenia não é conhecida. É de notar que as "linforragias" são encontradas, também, na artrite reumatóide, predominando, nesta última afecção, nos músculos estriados que podem ser sede de necroses e outras alteraçōes histológicas descritas no tipo 1 da miastenia grave. Vários autores ${ }^{29,78}$ salientam a semelhança destas lesões com as 
observadas na dermatomiosite e esclerodermia, pelo menos em certas fases da evolução. Recentemente alguns autores ${ }^{14,15}$ mostraram a existência de anomalias na arborização dos axônios terminais da junção neuromuscular em pacientes miastênicos, algumas especificas - placas displásicas - e outras não específicas - placas distróficas - estas ültimas também encontradas na distrofia muscular progressiva e nas polimiosites. Estudos histoquímicos mais recentes ${ }^{16,44}$ não mostraram alteraçōes das taxas de colinesterase nos músculos normais e miastênicos, o que dá mais ênfase às lesōes anátomo-patológicas acima referidas.

O miocárdio pode ser sede das mesmas lesões 4, 29,64: densos acúmulos de linfócitos no pericárdio e endocárdio, degeneração das fibras musculares, acúmulos de células, predominantemente de linfócitos, no tecido intersticial e em tôrno dos pequenos vasos, com degeneração das fibras adjacentes, edema e áreas de necrose. Estas lesões podem acarretar o aparecimento de sinais e sintomas clínicos de sofrimento do miocárdio, desde a taquicardia até a insuficiência cardíaca congestiva.

Em conclusão, do ponto de vista anátomo-patológico salientam-se, na miastenia grave, os seguintes fatos: 1) existência nos músculos, nas vísceras e no coração de lesões de tipo infiltrativo-celular (linforragias) com exsudato e edema, promovendo a degeneração das fibras adjacentes; 2) semelhança destas lesões com as encontradas na dermatomiosite; 3) possibilidade de evolução para lesões irreversiveis; 4) anomalias na arborização dos axônios terminais da junção neuromuscular, algumas específicas e outras não específicas, sendo que estas últimas foram encontradas também nas polimiosites.

Estas lesões anátomo-patológicas justificam o uso do ACTH para o tratamento da miastenia grave, seja em face das características histopatológicas, seja pela semelhança com as da dermatomiosite, da esclerodermia e da artrite reumatóide, em que os hormônios glicocorticóides têm indicação pela ação especifica inibidora que exercem sobbre os elementos linfóides.

\section{MÉTODO E MATERIAL}

Método - O tratamento fundamental foi feito pelo hormônio adrenocorticotrópico (ACTH "Armour" e Cortrofina "Organon") na dose de 2,5 a 25 mg, sempre pela via intravenosa, diluidos em 250 a $1.000 \mathrm{mi}$ de soluto glicosado a $5 \%$, administrado gôta a gôta, na velocidade média de 20 gôtas/minuto, durante 8 horas.

Em geral, nos primeiros dias de tratamento, o hormônio era diluído em $1.000 \mathrm{ml}$ de soluto. Como medicação associada foi administrada Prostigmina a todos os pacientes, substituida, depois, em alguns casos, pèla Mytelaze: a primeira foi usada pelas vias oral ou parenteral a a última soomente pela via oral. Como medicamentos adjuvantes foram usados o cloreto de potássio nas doses de 2 a $8 \mathrm{~g}$ por dia $\mathrm{e}$ o sulfato de efedrina nas doses de $25 \mathrm{mg}$ três vêzes ao dia, ambos pela via oral. Os pacientes foram mantidos em regime hiperprotéico e acloretado, sendo tomados todos os cuidados inerentes ao uso dos glicocorticóides.

A evolução foi acompanhada do ponto de vista clínico, sendo a sintomatologia classificada em 4 graus: 
1) Sintomatologia muito acentuada, nos casos em que os enfermos ficam imobilizados no leito, com paralisia acometendo também os músculos dependentes dos nervos cranianos e com insuficiência respiratória; êstes sintomas não respondem às drogas anticolinesterásicas.

2) Sintomatologia acentuada, caracterizada por impossibilidade do doente andar, de ficar de pé, ou de sentar-se no leito sem auxilio, com paresia acentuada dos territórios musculares dependentes dos nervos cranianos; impossibilidade de erguer a cabeça do travesseiro e provas deficitárias positivas para os quatro membros; possibilidade de crises respiratórias. Os sintomas não respondem às drogas anticolinesterásicas ou são muito pouco influenciados por elas.

3) Sintomatologia média em que a posição de pé e a deambulação são ainda possiveis embora dificultadas pela fadiga rápida; dificuldade para se levantar do leito; comprometimento menos acentuado do território muscular dos nervos cranianos, permitindo o fechamento das pálpebras (embora de modo fraco e incompleto) e sendo possível a deglutição de alimentos liqüidos e semiliqüidos; as provas deficitárias só são positivas após esfôrço; não há crises respiratórias; os sintomas são pouco influenciados pelas drogas anticolinesterásicas e logo deixam de responder às mesmas.

4) Sintomatologia leve que permite as atividades habituais do enfêrmo e, muitas vêzes, a própria atividade profissional; a sintomatologia responde bem às drogas anticolinesterásicas; os distúrbios, muito discretos, se restringem quase inteiramente a um dos setores do território muscular dos nervos cranianos.

Material - E representado por 10 pacientes portadores de miastenia grave corn sintomatologia acentuada ( 8 casos) e média ( 2 casos); todos vinham sendo tratados com drogas anticolinesterásicas (Prostigmina, Mestinon, Mytelaze), em doses adequadas, respondendo cada vez menos a esta terapēutica. Em alguns casos foram tentados outros tratamentos, como a telecobaltoterapia da região tímica, timectomia e denervação do seio carotídeo, sem resultados. É de notar que as remissões espontâneas neste grupo de doentes constituiram a exceção e, quando ocorreram, foram de curta duração. Os dados clínicos referentes a êstes 10 pacientes são, sintèticamente, os seguintes:

Caso 1 - B. A., com 35 anos, sexo masculino. Doença iniciada há 10 anos, com dificuldade para mastigar e deglutir alimentos e para ocluir as pálpebras. A doença vem piorando progressivamente. Jamais houve remissão espontânea dos sintomas que, entretanto, remitiam, no inicio, com Prostigmina; contudo os sintomas foram-se tornando resistentes a êste medicamento e a outras drogas. O paciente chegou a tomar $300 \mathrm{mg}$ diárias de Prostigmina sem remissão. O uso do Mestinon não trouxe melhoras. Quadro clássico de miastenia, com predominância dos distúrbios nos territórios musculares dos pares cranianos.

Caso 2 - A. B., com 26 anos, sexo feminino. Doença iniciada há 8 anos, com fraqueza e fadiga rápida dos músculos enervados pelos pares cranianos. De 7 anos para cá a paciente começou a usar Prostigmina, sendo necessárias doses cada vez maiores e com resultados cada vez mais precários. A enfêrma chegou a usar 150 mg de Prostigmina por dia e foi submetida à timectomia; após esta operação e radioterapia a doença piorou, a ponto de impedir a deglutição, a marcha e a movimentação ativa no leito. Quadro miastênico muito acentuado com voz anasalada, língua quase inerte na bôca; mastigação e deglutição impraticáveis; oftalmoplegia bilateral.

CASo 3 - C. A. S., com 49 anos, sexo feminino. Doença iniciada há 7 anos, com diplopia, fraqueza nos quatro membros e desordens da fala, marcha, degluticão e mastigação. A paciente já estivera internada com oftalmoplegia total e im- 
possibilidade de andar e de ficar de pé. Tratada com Prostigmina melhorou ràpidamente, restando, porém, ptose palpebral e diplopia que persistem até a data do exame atual, apesar do tratamento.

CASo 4 - R. V. S., com 24 anos, sexo feminino. Doença iniciada há 3 anos, com diplopia, disfagia, refluxo de líquiidos pelas fossas nasais, cansaço rápido durante a mastigação e voz anasalada. Estes sintomas agravaram-se ràpidamente, acompanhados de fraqueza e fadiga dos membros, dificultando a deambulação e a utilização das mãos. Surtos de insuficiência respiratória e grande dificuldade para se erguer do leito, apesar do uso da Prostigmina (270 $\mathrm{mg}$ diários). Transfusão de sangue de paciente miotônico não influenciou o quadro miastênico.

Caso 5 - I. D., com 16 anos, sexo feminino. Doença iniciada há 2 anos, com fraqueza e fadiga rápida dos membros inferiores, seguidas de comprometimento dos membros superiores. Agravação progressiva com impossibilidade de se erguer do leito e ficar de pé. Depois de alguns meses, dificuldade e fadiga rápida na mastigação e voz fraca e anasalada, dipiopia, estrabismo e ptose das pálpebras. A Prostigmina, que mantinha remissão dos sintomas no iniclo, foi-se tornando cada vez menos eficiente, mesmo em doses adequadas (90 $\mathrm{mg}$ por dia).

Caso 6 - A. V., com 31 anos, sexo masculino. Doença iniciada há 2 anos. Miastenia com predomínio no território dos pares cranianos: diplopia, ptose palpebral, voz anasalada, dificuldade à mastigação e à deglutição. Evolução para pior; só uma remissão espontânea de curta duração. De inicio os sintomas respondiam bem à Prostigmina, porém nos últimos meses houve acentuada e progressiva agravação, apesar do uso de $120 \mathrm{mg}$ diários dêste medicamento.

Caso 7 - D. R., com 20 anos, sexo feminino. Doença iniciada há 2 anos, com grande dificuldade para abrir a bôca, mastigar, deglutir, fechar as pálpebras; diplopia e cansaço fácil nos membros; ao se deitar a cabeça cai sôbre o travesseiro sem qualquer reação de defesa; grande dificuldade para se erguer do leito; voz anasalada.

Caso 8 - A. P., com 27 anos, sexo feminino. Doença iniciada há 4 anos, com fraqueza no pescoço e nas pernas; dificuldade para erguer a cabeça do travesseiro; diplopia e dificuldade para fechar as pálpebras. A doença vem evoluindo com periodos de piora e de melhora; durante os primeiros, muitas vêzes, a paciente tinha de ficar acamada, pois não conseguia se erguer do leito nem andar. Desde o início vem fazendo uso da Prostigmina com resultados cada vez menos favoráveis.

Caso 9 - J. A. S., com 18 anos, sexo masculino. Doença iniciada há 3 anos, com fraqueza e fadiga rápida nos quatro membros após infecção gripal. Agravação progressiva até impedir a deambulação. Há um més dificuldade na deglutição, voz anasalada e crises de insuficiência respiratória. Esta sintomatologia melhorava com a Prostigmina; a paciente chegou a tomar $240 \mathrm{mg}$ diàriamente. Exame neurológico; facies miastênica, ptose palpebral bilateral, paresia de ambos os faciais, fadiga rápida à mastigação, voz anasalada, cansaço rápido dos membros; marcha impossivel; o paciente não consegue se erguer do leito nem erguer a cabeça do travesseiro.

Caso 10 - C. M., com 29 anos, sexo masculino. Doença iniciada há um ano e meio. Cansaço fácil nos membros superiores; diplopia, ptose palpebral, voz anasalada, fadiga rápida à mastigação e à movimentação da língua, dificuldade para erguer a cabeça. Evolução progressiva com agravaçāo nestes últimos 6 meses; disfagia. Poucas melhoras com o uso da Prostigmina pela via oral; melhor resposta pela via parenteral. Piora apesar do aumento das doses de Prostigmina. Tumor do timo e timectomia com remissão da sintomatologia por 2 meses, seguida de piora lenta e progressiva que não respondia à Prostigmina (120 mg diàriamente). 
Em relação aos exames subsidiários ressaltaremos os seguintes fatos: Eletrodiagnóstico normal nos casos $1,2,7$ e 8 e com hipoexcitabilidade galvânica e farádica dos músculos mastigadores (caso 3 ) e dos glúteos (caso 5); em um único caso se obteve a reação miastênica de Jolly (caso 4). Nos 5 casos em que o eletrocardiograma foi feito foram observadas alterações em 4 (casos $4,5,8$ e 9). O exame eletrencefalográfico foi feito em dois casos, sendo normal em um (caso 2); no caso 4 houve suspeita de anormalidade paroxistica temporal. A eletromiografia mostrou atividade muito diminuida nos músculos masseter e frontal à direita no caso 4 . A radiografia simples do tórax resultou normal em todos os casos, exceto no caso 10 , em que revelou a presença de tumor na região ântero-superior do mediastino, e no caso 9 em que mostrou aumento da área cardiaca. A planigrafia foi normal nos casos 4, 5 e 7, confirmando o achado da radiografia simples no caso 9 . Em dois casos ( 5 e 7) foi feita a pneumomediastinografia que mostrou provável timo hiperplásico, devendo-se notar que nestes casos a radiografia simples e a planigrafia haviam sido normais. o exame do líqüido cefalorraquidiano foi normal em todos os casos. As provas para função tíreoidiana, inclusive captação do ${ }^{131}$ pela tireóide, foram normais. A eletromiografia da musculatura ocular extrínseca mostrou, em todos os casos em que foi feita, alterações caracteristicas da miastenia. Craniograma normal. Os exames de rotina nada de importante permitiram assinalar.

\section{TRATAMENTO E EVOLUÇAO}

Caso 1 - Agravação rápida do quadro miastênico, com graves distúrbios respiratórios apesar do uso intensivo da Prostigmina ( $30 \mathrm{mg}, 8$ a 10 vêzes ao dia), sendo necessárias a aspiração brônquica e o uso do oxigênio. Foi instituido o tratamento pelo ACTH: nos primeiros 4 dias foram administrados $12,5 \mathrm{mg}$ por dia; a seguir $10 \mathrm{mg}$ ( 6 dias) e $8 \mathrm{mg}$ por dia (12 dias); como houvesse ligeira agravação dos sintomas, a dose diária foi elevada para $10 \mathrm{mg}$ e assim mantida por mais 12 dias; como não houvesse melhora, a dose foi novamente elevada para $15 \mathrm{mg}$ diários e mantida por 27 dias, o que permitiu a remissão quase total do quadro miastênico; depois, a dose foi diminuída para 10 e $5 \mathrm{mg}$ até a alta hospitalar. A dose total de ACTH foi de $751 \mathrm{mg}$ em 64 dias (gráfico 1).

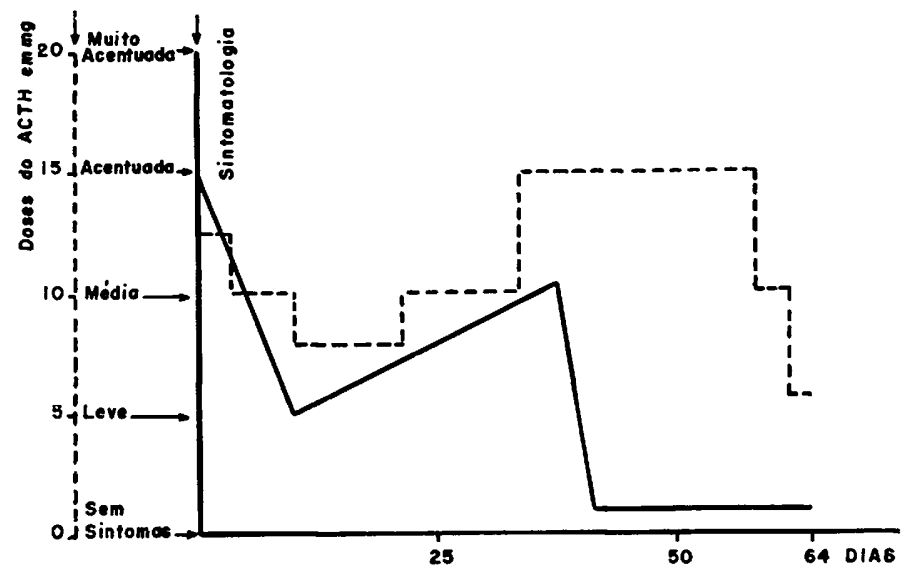

Gráfico 1 - Caso 1. Primeira série de ACTH (total $751 \mathrm{mg}$ ).

O paciente passou bem durante o primeiro mês após o término desta primeira série de ACTH e apenas os músculos orbiculares das pálpebras não tinham read- 
quirido, de modo completo, a sua fôrça. Depois reapareceram os sintomas miastênicos nos demais territórios musculares dos nervos cranianos, porém com pouca intensidade e assim permaneceram até dezembro de 1954, quando a sintomatologia novamente se agravou, porém sem nunca igualar o quadro que obrigou à internação anterior. Como não houvesse melhora dos sintomas com o uso da Prostigmina em doses aitas, o enfêrmo foi reinternado em 8-3-55, para ser feita nova série de $\mathrm{ACTH}$ : 12,5 mg nos primeiros 10 dias e, a seguir, $10 \mathrm{mg}$ (7 dias), $8 \mathrm{mg}$ (3 dias) e $5 \mathrm{mg}$ (2 dias); a seguir foi iniciada a administração da dose de manutenção de $5 \mathrm{mg}$, em dias alternados (5 aplicações) e, depois, cada 2 dias ( 7 aplicaçōes) (gráfico 2). A dose total do ACTH foi de $289 \mathrm{mg}$ em 47 dias. Alta em excelentes condições gerais e com remissão total dos sintomas. Este paciente vem sendo acompanhado até o presente momento: êle passa relativamente bem, está trabalhando e vem sendo mantido com doses baixas de Mestinon (meio comprimido 2 vêzes ao dia); apresenta apenas ligeira diminuição da fôrça do músculo orbicular das pálpebras dos dois lados e a voz levemente anasalada; as crises miastênicas graves não mais se repetiram.

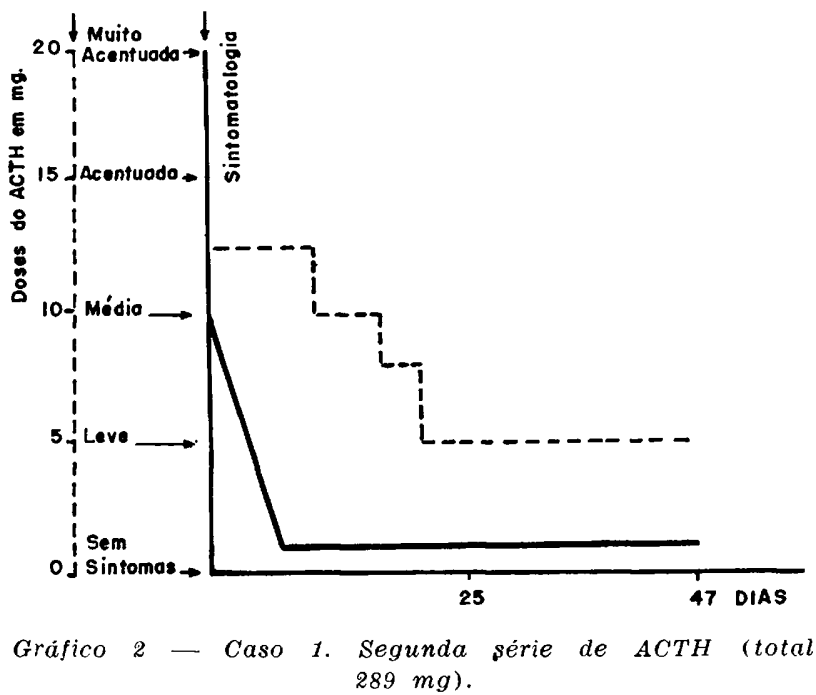

Caso 2 - Poucas melhoras foram conseguidas com o uso da Prostigmina nas doses de 75 a $150 \mathrm{mg}$ diários, nos primeiros dias de hospitalização. Cinco dias após o início do ACTH houve piora rápida dos sintomas a ponto de serem necessárias a traqueostomia e a aspiração brônquica. A seqüência da primeira série de tratamento pelo ACTH foi a seguinte: nos primeiros 3 dias, $12,5 \mathrm{mg}$ por dia; a seguir, $15 \mathrm{mg}$ durante 16 dias, depois $20 \mathrm{mg}$ durante 21 dias; em seguida as doses foram baixadas lenta e progressivamente para 15, 12,5, 10 e 8 mg num prazo de 3 semanas; finalmente, foram mantidos $10 \mathrm{mg}$ diários como dose de manutenção até a alta hospitalar que ocorreu em 19-9-53. A dose total de ACTH foi de $1.057,5 \mathrm{mg}$, em 93 dias de tratamento (gráfico 3 ).

A enfêrma passou bem no primeiro mês depois da alta, tendo reassumido suas atividades profissionais (datilógrafa). Manteve-se relativamente bem com o uso do Cortone por via oral ou muscular e Prostigmina ( 3 comprimidos ao dia), a partir da alta hospitalar até poucas semanas antes da segunda internação, determinada por seria agravação. Como acontecera na primeira hospitalização, a paciente foi internada em estado geral precário, pois nas últimas semanas tivera sua deglutição 


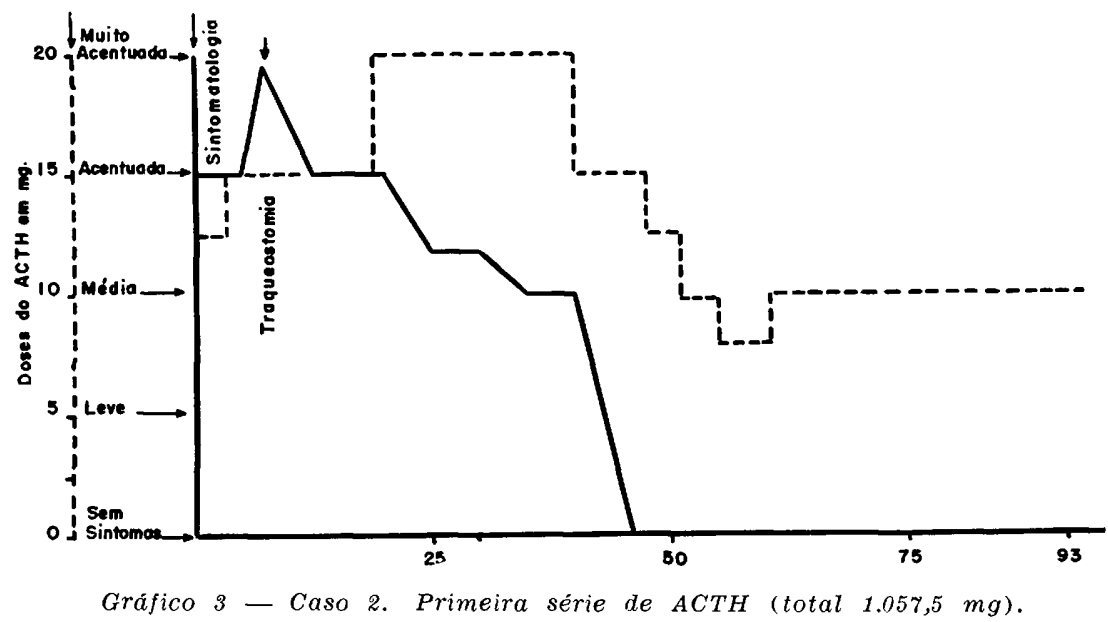

bastante comprometida, e se alimentara de modo deficiente. Houve, como na primeira série do ACTH, agravação alarmante dos sintomas na primeira semana de tratamento. A sequiência da segunda série do tratamento pelo ACTH foi a seguinte: $15 \mathrm{mg}$ nos primeiros 6 dias; como tivesse havido agravação da sintomatologia, a dose foi elevada para $25 \mathrm{mg}$ diários até o $12^{\circ}$ dia; ulteriormente passou a ser de $12,5 \mathrm{mg}$ durante 10 dias; a partir do $22^{\circ}$ dia de tratamento as doses foram diminuidas para $10 \mathrm{mg}$, porém tiveram que ser novamente elevadas para $12,5 \mathrm{mg}$ uma semana depois, em virtude do aparecimento de discretos distúrbios na deglutição e na fala; esta última dosagem foi mantida como dose de manutenção até a alta hospitalar, em 15-1-54. A dose total do ACTH foi de $\mathbf{5 2 5}$ $\mathrm{mg}$ em 36 dias de tratamento (gráfico 4). A paciente saiu do hospital em excelentes condições clinicas e gerais, com remissão quase total. Restava ligeira dificuldade na deglutição apesar do uso continuado da Prostigmina (3 comprimidos ao dia). Como medida de precaução foi mantida a traqueostomia e indicado o uso do Cortone por via muscular.

A paciente manteve-se relativamente bem até algumas semanas antes da terceira internação, em 10-12-1954, condicionada por rápida acentuação do quadro miastênico, com impressionante repercussāo para o lado do estado geral, exigindo administra-

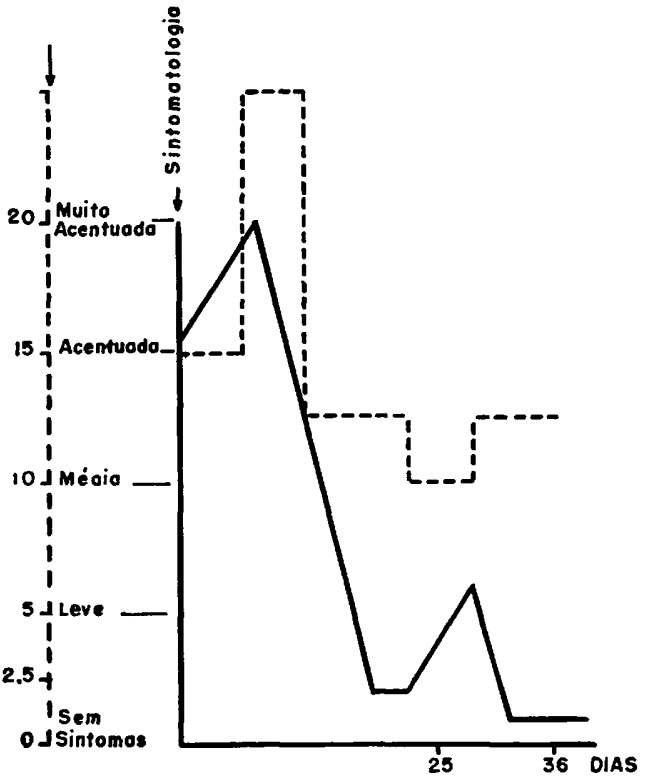

Gráfico 4-Caso 2. Segunda série de ACTH (total $525 \mathrm{mg}$ ). 
ção de oxigênio e de Prostigmina na veia, em virtude de dispnéia e impos. sibilidade de deglutição; a paciente mantinha-se completamente imobilizada no leito. A sintomatologia pouco ou quase nada se modificou com doses elevadas de Prostigmina usada por tôdas as vias. Após a primeira semana de ACTH as melhoras começaram a aparecer e foram se acentuando de modo lento, mas progressivo. Como das outras vêzes, na primeira semana do tratamento pelo ACTH houve agravação dos sintomas, não muito acentuada e que cedeu com elevação da dose do ACTH. Após um mês de tratamento as condições gerais e neurológicas eram excelentes, o pêso da paciente aumentou de 13 quilos; restavam, ainda, incompleto fechamento das pálpebras e ligeira alteração na deglutição. A sequiência desta terceira série do tratamento pelo $\mathrm{ACTH}$ foi a seguinte: nos primeiros 5 dias, $12,5 \mathrm{mg}$ por dia; no $6^{\circ}$ dia $20 \mathrm{mg}$; nos 5 dias subsequientes $12,5 \mathrm{mg}$; no $12^{\circ}$ dia $15 \mathrm{mg}$; nos 20 dias seguintes $12,5 \mathrm{mg}$; a partir do segundo mês $10 \mathrm{mg}$ por dia durante 10 dias, $8 \mathrm{mg}$ durante 4 dias e $5 \mathrm{mg}$ durante 10 dias; a seguir iniciamos a dose de $2,5 \mathrm{mg}$ em dias alternados e, depois, em vidtude de ligeira piora tentamos $5 \mathrm{mg}$ cada 2 dias e terminamos a série com $5 \mathrm{mg}$ em dias alternados; esta última dosagem foi considerada de manutençāo. Alta em 19-4-55. O total de ACTH foi de $354,5 \mathrm{mg}$ em 83 dias (gráfico 5).

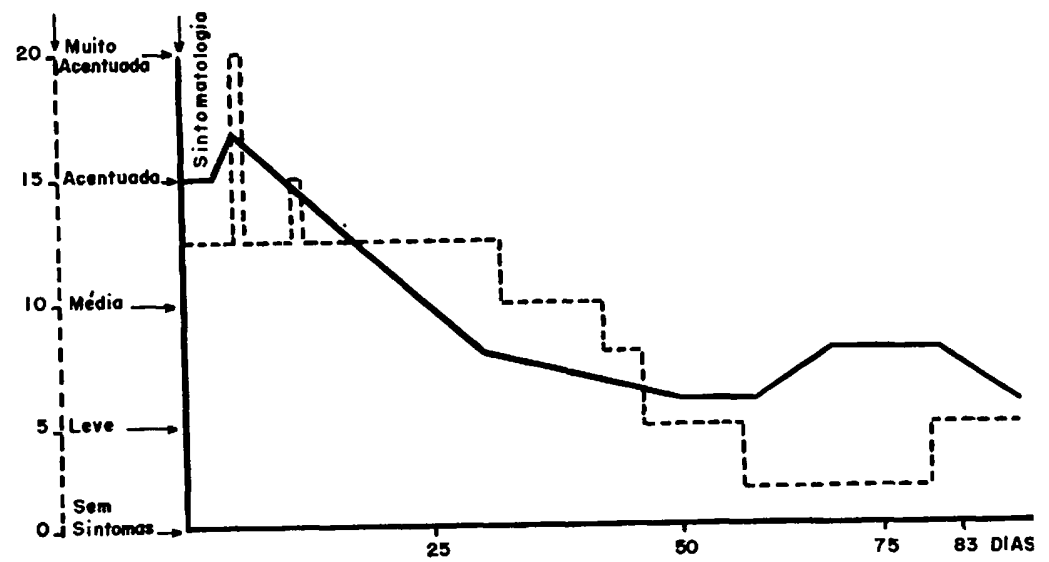

Gráfico 5 - Caso 2. Terceira série de ACTH (total $354,5 \mathrm{mg}$ ).

CAso 3 - A seqüência da série de tratamento pelo ACTH foi a seguinte: nos primeiros 7 dias foram feitos $12,5 \mathrm{mg}$ por dia; nos 15 dias restantes foram feitos $10 \mathrm{mg}$ por dia. A dose total de $\mathrm{ACTH}$ foi de $737,5 \mathrm{mg}$ em 22 dias. A diplopia e a ptose palpebral desapareceram completamente, havendo correção total do estrabismo. E de notar que esta remissão completa da oftalmoplegia se verificou pela primeira vez nos 3 anos da doença e coincidiu com o tratamento pelo ACTH. A paciente passou bem cêrca de um mês depois de terminado o tratamento, porém, a seguir, a diplopia e a ptose palpebral reapareceram, sendo esta última pouco evidente e apenas observável em OD. Nenhuma outra manifestação surglu e a enfèrma vem exercendo até o presente momento tôdas as suas atividades habituais.

Caso 4 - Após 5 dias sem qualquer tratamento, foi feito o teste da Prostigmina com resposta positiva. A seguir, foi administrada a Prostigmina nas doses de $15 \mathrm{mg}$ quatro vêzes ao dia pela via oral com melhoras acentuadas, exceto da oftalmoplegia que permaneceu irredutivel. A partir da segunda semana seguiu-se piora progressiva apesar da manutenção da droga anticolinesterásica: a paciente não 
consegue sentar-se sòzinha no leito e nem mesmo erguer a cabeça do travesseiro; mastiga e deglute de modo precário e continua apresentando oftalmoplegia total. Em virtude do aparecimento de efeitos colaterais da Prostigmina foi administrado sulfato de atropina, suspenso alguns dias depois em virtude do aparecimento de fenômenos tóxicos. Logo a seguir surgiram crises respiratórias intervaladas por alguns dias de remissão, e debeladas com a Prostigmina pela via muscular. Uma transfusão de sangue de paciente portador de miotonia nāo influenciou a sintomatologia miastênica; esta transfusão foi precedida pela suspensão temporária da medicação anticolinesterásica e não foi acompanhada de qualquer efeito colateral. Os surtos de asfixia foram se tornando cada vez mais freqüentes e mais graves, sendo acompanhados de intensa sudorese, cianose e agitação psicomotora; durante as crises mais graves a doente ficava inconsciente e, algumas vêzes, apresentava manifestações epileptiformes. Foi iniciado o ACTH na dose de $12,5 \mathrm{mg}$, diàriamente, passando a Prostigmina a ser administrada em doses bem maiores (3 comprimidos 6 vêzes ao dia). Em virtude da agravação das desordens respiratórias 0 ACTH foi suspenso, tendo havido melhora parcial do quadro miastênico logo após a suspensão do hormônio. A seguir, novas e mais graves crises respiratórias foram se sucedendo, agora diàriamente, obrigando o emprêgo da medicação anticolinesterásica em doses elevadas (270 $\mathrm{mg}$ nas 24 horas) pelas vias oral, muscular e intravenosa, a traqueostomia e a respiração artificial. Foi reiniciado o ACTH, na seguinte seqüēncia: $12,5 \mathrm{mg}$ por 12 dias, $15 \mathrm{mg}$ por 2 dias, e $20 \mathrm{mg}$ durante 5 dias;

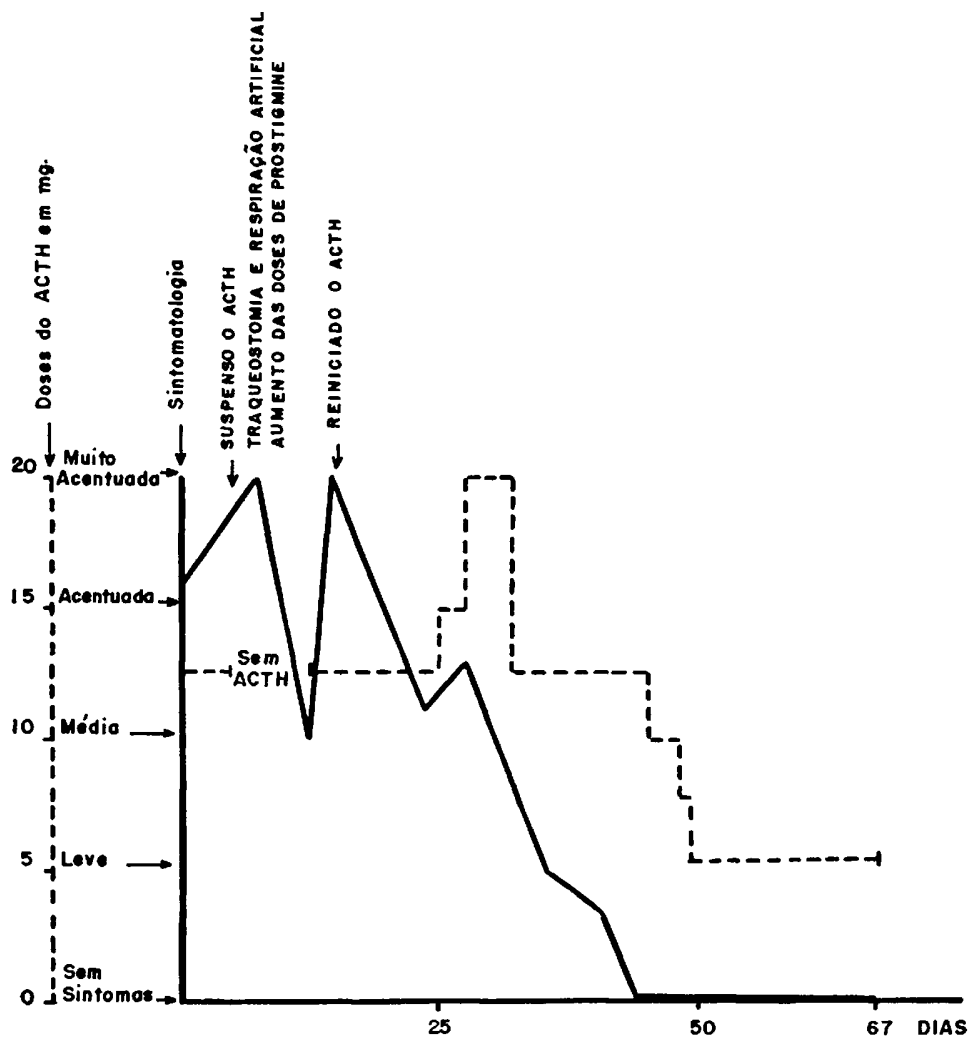

Gráfico 6 - Caso 4. Dose total de ACTH: $633 \mathrm{mg}$. 
a seguir, as doses foram baixadas para $12,5 \mathrm{mg}$ por 13 dias, $10 \mathrm{mg}$ por 3 dias, $8 \mathrm{mg}$ por 1 dia e $5 \mathrm{mg}$ por 18 dias. As melhoras se processaram de modo lento mas progressivo, não tendo sido necessário o uso do respirador mecânico.

$\mathrm{Na}$ ocasião da alta (1-7-57) o estado geral da enfêrma era excelente, o estado de nutrição muito bom (houve acentuado aumento de pêso) e os sintomas e sinais da miastenia se mantinham em remissão completa, tendo cedido as crises de insuficiência respiratória. A dose total de ACTH administrada foi de $633 \mathrm{mg}$ durante 67 dias.

Caso 5 - Durante todo o periodo de exames a paciente foi tratada exclusivamente pela Prostigmina na dose de 3 comprimidos ao dia; o quadro miastênico melhorou sensivelmente nos primeiros dias de tratamento, para depois estacionar e sofrer uma piora, o que obrigou ao aumento de dose da medicação para 6 comprimidos diários, sem que, apesar disso, a sintomatologia fôsse influenciada. A miastenia continuou se agravando a ponto de imobilizar a paciente no leito; ela nāo mais conseguia se erguer nem andar sem apoio, e nem sequer levantava a cabeça do travesseiro. O aumento progressivo da dose de Prostigmina não influenciou êste estado. Nestas condiçōes, foi iniciado o tratamento com ACTH $(12,5 \mathrm{mg}$ diários durante 27 dias), na dose total de $337,5 \mathrm{mg}$. As melhoras se processaram de modo rápido no comêço e depois menos ràpidamente, mas de modo progressivo, tendo havido piora transitória e discreta a partir do $20^{\circ}$ dia, ocasião em que foi suspensa a Prostigmina. Esta droga vinha sendo administrada na dose de 3 a 4 comprimidos diários durante todo o periodo de tratamento pelo ACTH, exceto por dois dias a partir do $20^{\circ}$ dia do inicio da terapêutica hormonal. A administração da droga promoveu nova remissão (gráfico 7). A paciente passou a se erguer sozinha do leito, a andar e a se alimentar normalmente; os músculos oculares se normalizaram, tendo desaparecido a diplopia. Desde que teve alta, se apresenta em remissão completa. A Prostigmina foi substituida pela Mytelaze, na dose de $50 \mathrm{mg}$ diários. Até o momento (6-11-59) a paciente está passando muito bem, exercendo suas atividades profissionais.

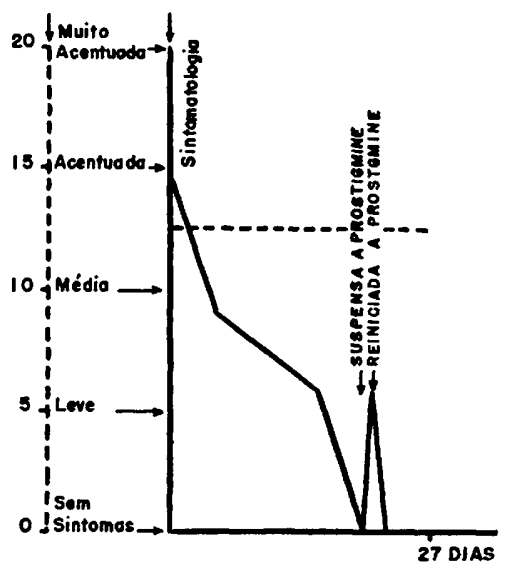

Gräfico 7 - Caso 5. Dose total de ACTH: $33 \%, 5 \mathrm{mg}$.

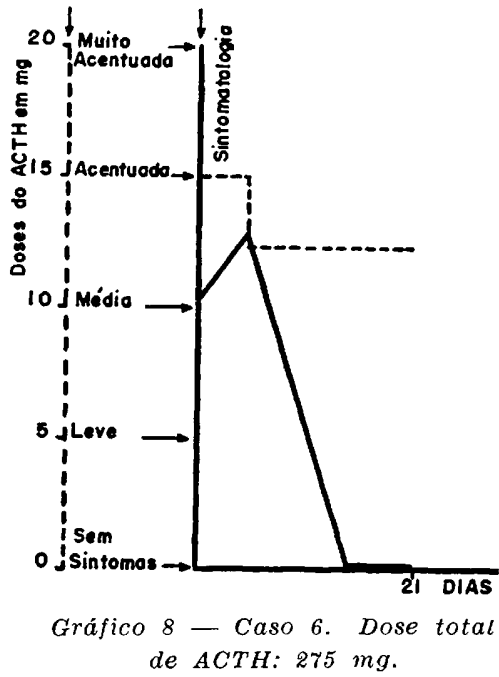

de $A C T H: 275 \mathrm{mg}$.

Caso 6 - Antes de começar o ACTH o paciente estava em uso da Prostigmina pelas vias oral e parenteral em doses adequadas sem melhoras evidentes. Foi iniciado o ACTH na seguinte sequiencia: $15 \mathrm{mg}$ durante 5 dias e 12,5 $\mathrm{mg}$ durante 
16 dias. O paciente tomou $275 \mathrm{mg}$ de ACTH em 21 dias. Houve acentuada e rápida melhora do quadro miastēnico, inclusive nos territórios musculares dos pares cranianos, pois a voz se normalizou e bem assim a deglutição e a mastigaçāo; a marcha estava normal e bem assim a respiração na ocasião da alta. Nos primeiros dias da administração do ACTH houve agravação dos sintomas, especialmente da diplopia, sem, no entanto, haver sinais e sintomas de insuficiência respiratória. As melhoras começaram a aparecer a partir do $5^{\circ}$ dia do tratamento e se processaram de modo muito rápido (gráfico 8). Durante todo o transcurso da hormonioterapia a Prostigmina foi administrada na dose de 2 comprimidos 4 vêzes ao dia.

Caso 7 - Poucas melhoras foram conseguidas com o uso da Prostigmina pela via oral na dose de $60 \mathrm{mg}$ diários. A elevação dessa dose foi seguida de piora do quadro miastênico, inclusive com o aparecimento de moderada crise respiratória, pelo que foi feita a telecobalterapia da região do mediastino anterior e superior. Foram feitas $200 \mathrm{r}$ por dia, num total de $3.000 \mathrm{r}$. No decurso dêste tratamento a paciente queixou-se freqüentemente de dor retrosternal (mediastinite?); nada mais de importante foi verificado, inclusive para o lado do sangue controlado por exames hematológicos periódicos. Como não apresentasse melhora evidente com os tratamentos supracitados, foi feito o ACTH pela via intravenosa, em aplicações diárias de $12,5 \mathrm{mg}$, num total de $337,5 \mathrm{mg}$ em 27 dias. Houve melhora acentuada: a paciente conseguia erguer-se sem dificuldade do leito, aumentou a fôrça em todos os territórios musculares e a marcha, a deglutição e a mastigação se normalizaram. A única queixa da paciente era falta de fôrça para falar, embora a voz fôsse normal (gráfico 9).

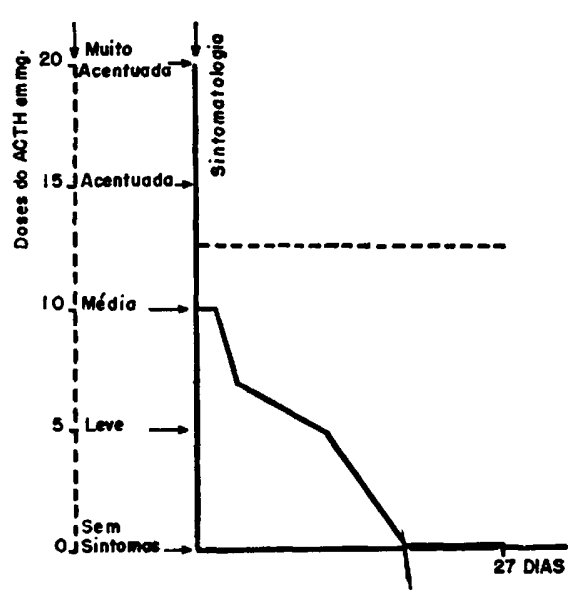

Gráfico 9 - Caso 7. Dose total de ACTH: $397,5 \mathrm{mg}$.

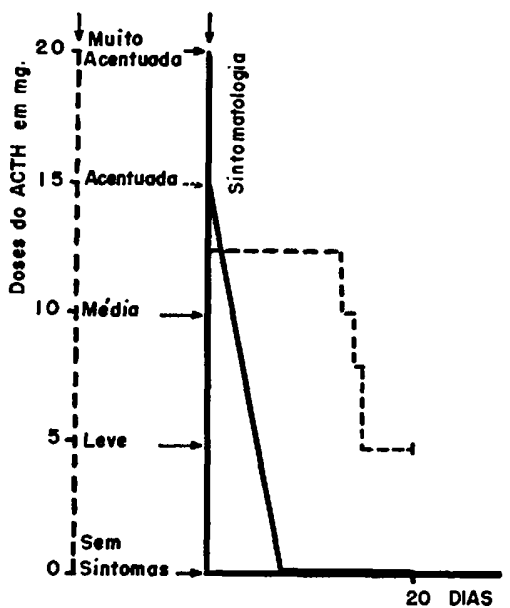

Gráfico 10 - Caso 8. Dose total de ACTH: $205,5 \mathrm{mg}$.

CASo 8 - Fol continuado o tratamento com Prostigmina pela via oral em doses eficientes e cada vez majs altas sem resultado favorável. Administrado o ACTH na seguinte sequiência diária: $12,5 \mathrm{mg} 13$ dias, $10 \mathrm{mg} 1 \mathrm{dia}, 8 \mathrm{mg} 1$ dia, e $5 \mathrm{mg} 5$ dias. Dose total de $205,5 \mathrm{mg}$ em 20 dias. A Prostigmina foi administrada na dose de 3 comprimidos por dia. As melhoras se procesasram de modo muito rápido e sem qualquer complicação (gráfico 10). Alta em excelentes condições gerais e de nutrição e com remissão completa de todos os sinais e sintomas. Esta paciente vem sendo controlada no ambulatório e continua passando perfeitamente bem. A Prostigmina continuou sendo usada na dose de 3 a 4 comprimidos por 
dia, tendo sido substituída, recentemente, pela Mytelaze com vantagem segundo nos informou a própria doente; a dose ótima para o caso foi de $30 \mathrm{mg}$ diàriamente.

CAso 9 - Durante as duas primejras semanas foi administrada a Prostigmina na dose de 12 comprimidos ao dia, aumentada depois de alguns dias, para 16 comprimidos diàriamente em virtude de agravação dos sintomas miastênicos, inclusive com o aparecimento de crises de dispnéia. A sintomatologia foi muito pouco influenciada pela Prostigmina. $\dot{E}$ de notar que nos primeiros dias de internação o doente foi acometido de processo agudo febril de etiologia năo esclarecida, o que

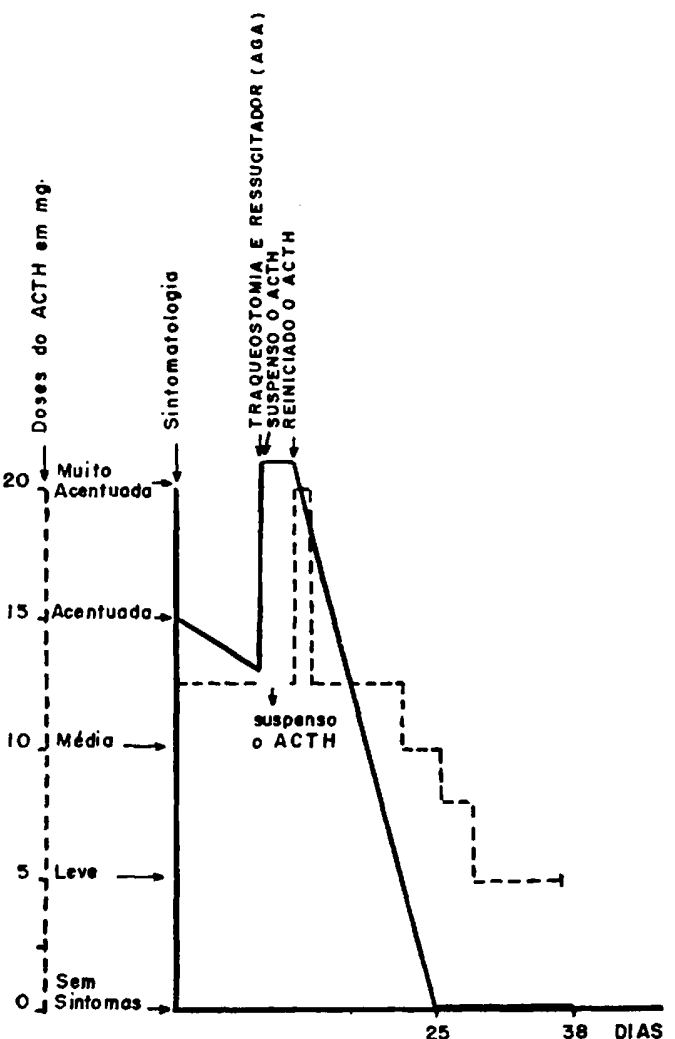

Gráfico 11 - Caso 9. Dose total de ACTH. $349 \mathrm{mg}$. agravou o quadro miastênico. Cessada a infecção, foi feito o ACTH (12,5 $\mathrm{mg}$ por 8 dias), sendo mantida a Prostigmina na dose de 16 comprimidos ao dia. Houve discreta melhora nesta primeira semana de tratamento. No $80 \mathrm{dia}$, entretanto, ocorreu grave crise respiratória, com agravação muito acentuada dos sintomas miastênicos, aumento das secrecões das vias aéreas e hipersialorréia, o que obrigou à traqueostomia de urgência, ao emprêgo do ressuscitador (AGA), à administração de atropina pela via muscular na dose de $1 / 2 \quad \mathrm{mg}$ 8-8 horas $\mathrm{e}$ depois $1 / 4 \mathrm{mg}$ 6-6 horas, além de Prostigmina pela via intravenosa; o ACTH foi interrompido e reiniciado, 3 dias depois, na seguinte seqüência: $20 \mathrm{mg}$ 1 dia, e $12,5 \mathrm{mg} 10$ dias; na última semana de tratamento as doses do hormónio foram baixadas progressivamente para $10 \mathrm{mg}, 8 \mathrm{mg}$ e $5 \mathrm{mg}$. A dose total de ACTH administrada foi de $349 \mathrm{mg}$ em 38 dias. Houve melhora discreta dos sintomas até o $8^{\circ}$ dia do início do ACTH, quando apareceu a crise respiratória acima referida; a seguir, as melhoras se processaram de modo rápido e progressivo até a remissão completa da sintomatologia. No final do tratamento a Prostigmina estava sendo administrada na dose de 6 comprimidos ao dia e assim foi mantido mesmo após a alta (gráfico 11).

Caso 10 - Apesar das doses adequadas de Prostigmina (6 comprimidos de 15 $\mathrm{mg}$ por dia), o quadro miastênico continuou piorando, tendo aparecido insuficiência respiratória, em crises, sendo que uma delas, muito grave, só remitiu com 3 ampôlas de Prostigmina na veia. Por estas razões foi mantido o oxigênio, refeita a traqueostomia e aumentadas as doses de Prostigmina ( 2 comprimidos 4 vêzes ao dia). Iniciado o ACTH na dose de $12,5 \mathrm{mg}$ o paciente continuou sem alteraçōes até a 5a aplicação, quando apresentou séria agravação do quadro miastênico com grave crise de insuficiência respiratória e acentuado aumento das secreções nas vias aéreas, o que obrigou o emprêgo do respirador artificial; a dose de ACTH foi 
elevada para $15 \mathrm{mg}$ ao dia nas 48 horas seguintes e depois para $20 \mathrm{mg}$ ao dia por mais 36 horas; foram feitas injeçoes intramusculares de sulfato neutro de atropina 1/2 mg de 8-8 horas, aspiraçōes frequientes através da cânula de traqueostomia, e suspensa a Prostigmina pela via oral (havia dúvidas quanto a uma possivel reação colinérgica); com estas medilas houve acentuada melhora, inclusive da hipersecreção das vias aéreas que ficou reduzida ao minimo. Após 48 horas, o pa-

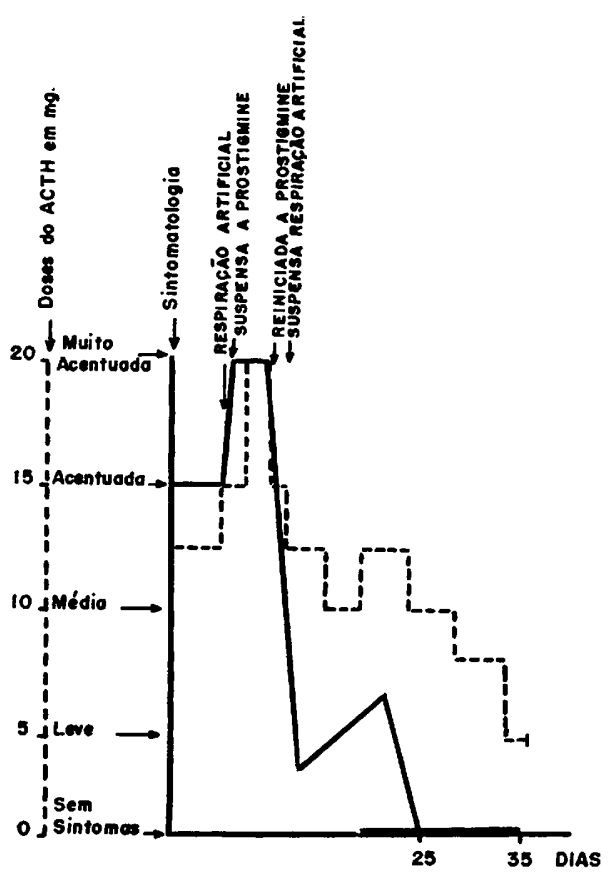

Gráfico 12 - Caso 10. Dose total de ACTH: $412,5 \mathrm{mg}$. ciente foi retirado do pulmão de aço, e adaptado à cânula da traqueostomia o respirador tipo AGA, que também foi retirado ao fim de mais 48 horas. A seguir, não mais foi necessária a respiração artificial, pois o enfêrmo prosseguiu melhorando ràpidamente a ponto de, na 10a aplicação de $\mathrm{ACTH}$ (a contar do início da crise miastênica), os sintomas miastênicos terem remitido quase que completamente; restava apenas certa dificuldade na deglutição. As doses de ACTH foram sendo baixadas de modo progressivo na seguinte ordem: $20 \mathrm{mg} 3$ dias, $15 \mathrm{mg}$ 1 dia, $12,5 \mathrm{mg} 5$ dias, $10 \mathrm{mg} 3$ dias; a seguir, retôrno às doses de 12,5 $\mathrm{mg}$ mais 5 dias, em vista de ligeira piora dos sintomas, e depois $10 \mathrm{mg}$ 4 dias, $8 \mathrm{mg}$ mais 5 dias e $5 \mathrm{mg}$ nos 2 últimos dias. A dose total de ACTH foi de $412,5 \mathrm{mg}$, em 35 dias (gráfico 12). A Prostigmina foi administrada desde o comêço na dose de 4 e depois 6 comprimidos ao dia; esta polosogia foi aumentada para 2 comprimidos 4 vêzes ao dia desde que se iniciou o ACTH e, durante um dia, 6 vêzes (12 comprimidos nas 24 horas) para, a seguir, coincidindo com séria agravação do quadro

miastênico, ser suspensa durante 4 dias (gráfico 12), ao passo que a dose de ACTH era aumentada de $12,5 \mathrm{mg}$ para 15 e depois $20 \mathrm{mg}$ ao dia. Depois da remissão da crise a Prostigmina foi administrada em aoses menores ( 3 comprimidos ao dia) durante 19 dias, e depois em doses maiores (6 comprimidos ao dia) mais 6 dias. Finalmente, no final da série de ACTH, a Prostigmina foi substituida pela Mytelaze, 2 comprimidos de $25 \mathrm{mg}$ ao dia durante 10 dias e depois um ao dia após a alta. Na ocasiāo da alta a miastenia estava em remissão completa. O estado geral e de nutrição era excelente. Este paciente está sendo acompanhado e até o momento passa bem.

\section{COMENTARIOS}

Apesar do pouco entusiasmo manifestado por muitos autores $32,41,73,77$ pelo emprêgo do ACTH no tratamento da miastınia grave, iniciamos êste método terapêutico nos casos com sintomatologia acentuada e nos de média intensidade, utilizando a via intravenosa para a administração do hormônio ${ }^{2}$. 
Várias razões justificavam a nossa orientação. Há tendência em admitir que a miastenia grave seja conseqüente à diminuição da sintese da acetilcolina e uma vez que o ACTH aumenta a capacidade de síntese da acetilcolina in vitro e in vivo, é de supor que o uso dêste hormônio seja útil no tratamento da miastenia. Por outro lado, os tecidos linfóides e o timo que não sofrem a involução fisiológica nos pacientes miastênicos, e até podem evoluir no sentido de hiperplasia ou de hipertrofia, atuariam, mediante a elaboração de substâncias inibidoras, no sentido de diminuir a síntese da acetilcolina: ora êstes tecidos são reduzidos em massa e em pêso pela ação do ACTH e, assim, êste hormônio, além de agir diretamente no sentido de aumentar a síntese da acetilcolina, agiria indiretamente, pela redução dos tecidos linfóides e do timo. $\dot{E}$ preciso considerar também, que as lesões encontradas nos músculos estriados e no coração, na vigência de miastenia (infiltrações linfocitárias e reaçōes inflamatórias exsudativas em que o edema assume, por vêzes, grandes proporções), podem ser inbluenciadas benèficamente pelo ACTH. Deve ser salientada, ainda, a grande semelhança das alterações histológicas, em certas fases da evolução da miastenia grave, com as encontradas na dermatomiosite, na esclerodermia e na artrite reumatóide, afecções em que os hormônios glicocorticóides têm perfeita indicação; o ACTH poderia impedir que as lesões ainda reversíveis se tornem irreversiveis, com danos definitivos para a fibra muscular que entraria em degeneração e atrofia em alguns casos. Por último, deve ser lembrado que os autores que utilizaram o ACTH no tratamento da miastenia grave até agora, o fizeram de modo arbitrário, em doses variáveis, em geral elevadas, sempre pela via muscular, em séries de duração diversa, porém na maioria das vêzes de curta duração, em geral não mais de 8 dias. Os resultados obtidos com a cortisona foram sempre menos favoráveis que com o ACTH ${ }^{73}$.

Pelos resultados obtidos em nossos pacientes julgamos excessivo o descrédito com que alguns autores consideram esta terapêutica. Foram as formas de sintomatologia acentuada as que responderam melhor ao tratamento. Alguns dos casos aqui registrados estavam respondendo pouco e cada vez menos às drogas anticolinesterásicas, e outros não mais respondiam a estas drogas, inclusive ao Mestinon e ao Mytelaze, quando se decidiu o emprêgo do ACTH. Dêstes casos, a maioria não tinha tido qualquer periodo de remissão espontânea anterior, e dois dêles haviam apresentado uma única remissão espontânea e de curta duração (casos 2 e 6). Em dois pacientes havia sido feita a timectomia, sendo um com hiperplasia do timo (caso 2) e outro com timoma (caso 10); em ambos houve agravação acentuada da doença após a intervenção cirúrgica.

Dois pacientes foram submetidos prèviamente a irradiação do timo, inclusive pela telecobaltoterapia ( $\operatorname{casos} 7$ e 10), sem qualquer melhora. Um dos pacientes foi submetido à denervação do seio carotídeo (caso 6) sem resultado benéfico. 
Em quase todos os pacientes tratados pelo ACTH as doses de Prostigmina foram elevadas no inicio do tratamento ou durante a agravação do quađro miastênico, para serem reduzidas ulteriormente.

Em uma paciente (caso 2) a Prostigmina chegou a ser suspensa transitòriamente sem que por isso a sintomatologia houvesse reaparecido; esta mesma enfêrma passou a ser mantida, ulteriormente, com doses pequenas de Prostigmina ( 3 comprimidos ao dia) e, mais recentemente, com Mytelaze, ao qual houve melhor resposta. Além dêste, outros pacientes vêm respondendo melhor ao uso do Mytelaze (casos 5, 8 e 10) após o tratamento pelo ACTH.

Dos casos tratados pelo ACTH, em 6 houve agravação dos sintomas miastênicos dentro dos primeiros 10 dias de tratamento; isso ocorreu no caso 1 (primeira série do $\mathrm{ACTH}$, gráfico 1 ), no caso 2 (gráficos 3,4 e 5) e nos casos 4, 6, 9 e 10 (gráficos 6, 8, 11 e 12); a agravação foi muito acentuada, tendo sido necessária a traqueostomia nos casos 2, 4, 9 e 10 , sendo que os três últimos necessitaram, ainda, de respiração artificial. No caso 1 a agravação foi lenta e se iniciou no $100^{\circ}$ dia de tratamento, coincidindo com redução da dose do ACTH (gráfico 1); na segunda série obteve-se a remissão rápida e quase completa dos sintomas (gráfico 2). Nos casos 4 e 9 o hormônio foi suspenso transitòriamente no acme da crise miastênica (gráficos 6 e 11). Em todos os casos o aumento das doses do ACTH ou o seu reinício com doses mais altas, promoveu a remissão da sintomatologia. Em dois casos (na segunda série do caso 2 e no caso 5) houve ligeira agravação da miastenia quase no final do tratamento: no primeiro (gráfico 4) bastou moderada elevação das doses diárias do ACTH, de 10 para $12,5 \mathrm{mg}$, para promover a remissão completa, pois a piora coincidiu com a diminuição das doses; no segundo (gráfico 7), a agravação dependeu da suspensão da Prostigmina, e foi logo corrigida com a administração desta droga. É preciso, ainda, ressaltar que no caso 2 houve remissão lenta da miastenia na terceira série de $\mathrm{ACTH}$ após crise miastênica moderada inicial, porém não se conseguiu remissão completa (gráfico 5). Em todos os casos, exceto na terceira série de ACTH do caso 2, foi obtida remissão completa ou quase completa da sintomatologia.

Entretanto, a agravação dos sintomas miastênicos não constitui complicação que se verifique em todos os pacientes tratados pelo ACTH, pois isso não foi observado em 4 dos 10 casos (casos 3, 5, 7 e 8). É óbvio que com apenas 10 casos não podemos tirar conclusōes estatísticas, porém não deixa de ser significativo o fato de 4 pacientes não terem apresentado a crise miastênica na vigência da terapêutica hormonal.

A agravação dos sintomas durante a administração do ACTH poderia resultar de desordens em muitas fases do metabolismo 18, 81: diminuição de glutationa do sangue, aumento da secreção de muitos hormônios esteróides, efeitos adversos sôbre o metabolismo dos hidratos de carbono e alterações do balanço eletrolítico do organismo. Segundo Torda e Wolff ${ }^{86}$ tôdas estas alterações dificultam ou impedem a sintese da acetilcolina e agravam os 
sintomas da miastenia. Para outros autores ${ }^{32}$ o mecanismo desta exacerbação da miastenia durante o tratamento pelo ACTH poderia ser atribuido a possível baixa do potássio intracelular.

\section{CONCLUSOES}

1) O hormônio adrenocorticotrópico da hipófise (ACTH), usado por via intravenosa, representa importante contribuição na terapêtica da miastenia grave.

2) Este novo método de tratamento encontra apoio em bases bioquímicas, fisiopatológicas e anátomo-patológicas.

3) O ACTH torna a sintomatologia miastênica mais sensível às drogas anticolinesterásicas, permitindo o contrôle dos sintomas por tempo mais prolongado com doses menores de medicamento.

4) Durante a administração do $\mathrm{ACTH}$ é obrigatório o uso da medicação anticolinesterásica associada, devendo as doses serem aumentadas nos primeiros 10 dias e mantidas, em posologia variável para cada caso, mas quase sempre mais baixa, durante o periodo restante e após o término do tratamento hormonal. A administração do cloreto de potássio é compulsória sỏmente durante as aplicações do $\mathrm{ACTH}$, sendo facultativo o uso do sulfato ou do cloridrato de efedrina como medicação adjuvante.

5) Os casos de miastenia acentuada e os de média intensidade que respondem pouco ou nada às drogas anticolinesterásicas são os que mais se beneficiam com o tratamento pelo ACTH. O ACTH é também indicado nos casos em que foram empregados outros tratamentos (timectomia, denervação do seio carotídeo e irradiação do timo) e que sofreram agravação imediata ou tardia apesar do uso da medicąção anticolinesterásica em dosagens adequadas.

6) O tratamento pelo ACTH intravenoso deve ser feito em hospital adequado para atender as crises respiratórias, em virtude da agravação, por vêzes acentuada, dos sintomas miastênicos na vigência da terapêutica hormonal.

\section{RESUMO}

O autor inicia o trabalho referindo as bases bioquímicas, fisiopatológicas e anátomo-patológicas do tratamento da miastenia pelo ACTH. Na miastenia grave há diminuição da sintese da acetilcolina no organismo, atuando o ACTH no sentido de aumentar esta sintese seja diretamente, por ativação da colinacetilase, seja indiretamente, mediante a redução da massa dos tecidos linfóides, em particular do timo, responsáveis pela elaboração de substâncias que diminuem a sintese da acetilcolina. 
O autor empregou o ACTH "Armour" e a Cortrofina "Organon", nas doses de 2,5 a $25 \mathrm{mg}$, sempre pela via intravenosa, diluídos em 250 a $1.000 \mathrm{ml}$ de soluto glicosado a $5 \%$, administrado gôta a gôta, na velocidade média de 20 gôtas por minuto, durante 8 horas. Como medicação associada foi administrada a Prostigmina a todos os pacientes, substituída, depois, em alguns casos, pelo Mestinon ou pela Mytelaze. Como adjuvantes foram empregados o cloreto de potássio ( 2 a $8 \mathrm{~g}$ por dia) e o sulfato de efedrina (25 $\mathrm{mg} 3$ vêzes ao dia). Os pacientes foram mantidos em regime hiperprotéico e acloretado, sendo tomados todos os cuidados inerentes ao uso do ACTH.

Foram estudados 10 pacientes portadores de miastenia com sintomatologia acentuada ( 8 casos) e média ( 2 casos). Todos os doentes vinham sendo tratados com drogas anticolinesterásicas em doses adequadas (Prostigmina, Mestinon, Mytelaze) e a sua sintomatologia respondia cada vez menos a esta terapêutica. Em alguns casos haviam sido tentados outros tratamentos (timectomia, denervação do seio carotídeo, irradiação da região tímica) sem resultado. É de notar que as remissões espontâneas neste grupo de enfermos foram excepcionais e de curta duração. A evolução foi acompanhada do ponto de vista clinico, com a sintomatologia classificada como muito acentuada, acentuada, média e leve. Em todos os casos houve remissão completa ou quase completa da sintomatologia após dosagens variáveis de $\mathrm{ACTH}$; no caso 2, por exemplo, sỏmente na terceira série de $\mathrm{ACTH}$, foi conseguida remissão da sintomatologia acentuada para leve. Dos 10 casos relatados neste trabalho, em 6 houve agravação dos sintomas miastênicos nos primeiros 10 dias de tratamento.

$\mathrm{O}$ autor considera o ACTH, utilizado por via intravenosa, como importante contribuição na terapêutica da miastenia grave, sendo especialmente indicado nas formas severas que não regridem mediante o emprêgo dos medicamentos anticolinesterásicos habitualmente usados.

\section{SUMMARY}

Treatment of severe forms of myasthenia by intravenous administration of ACTH.

The author presents the biochemical, physiopathological and anatomopathological bases of the treatment of myasthenia gravis by ACTH. In this disease there is a reduction of the synthesis of acetylcholine in the body; ACTH stimulates this synthesis, diretly by activation of cholinacetylasis, or indirectly, through reduction of the mass of lymphoid tissues, especially of the thymus, which are responsible for the elaboration of substances which reduce the synthesis of acetylcholine.

The author used ACTH "Armour" and Cortrophine "Organon", in the doses of 2.5 to $25 \mathrm{mgm}$., diluted in 250 to $1,000 \mathrm{ml}$. of a $5 \%$ glycose solution; administration was always by intravenous way, in an average rate 
of $20 \mathrm{drops} / \mathrm{minute}$, during 8 hours. As associate medication all patients received Prostigmin, which was later replaced, in some cases, by Mestinon or Mytelaze. As accessory medicaments were used potassium chloryde (2 to 8 grams per day) and ephedrine sulfate (25 mgm. 3 times a dayly). Patients were kept in an hyperproteic and achlorated diet and all precautions indicated when using ACTH were employed.

Ten patients with myasthenia were studied. All patients had been treated before with anticholinesterasic drugs (Prostigmin, Mestinon, Mytelaze) in proper doses and their reaction to this therapy decreased gradually. In some cases other treatments had been tried thymectomy, denervation of the carotid sinus, radiation of the thymic region) without any result. Spontaneous remission in this group of patients were exceptional and for only short periods. Evolution was followed up from the clinical point of view. In all cases complete or almost complete remission occurred after a variable dosage of ACTH. In case 2, for instance, only after the 3rd series of ACTH remission of a severe symptomatology to a slight one was attained. In 6 of the 10 cases myasthenic symptoms became worse during the first 10 days of treatment. The author considers intravenous administration of $\mathrm{ACTH}$ as an important contribution to the therapy of myasthenia gravis, being especially indicated in the severe forms, which does not decrease through the use of anticholinesterasic drugs usually employed.

\section{REFERẼNCIAS}

1. ARK-UPMARK, E. - Cardiovascular observations in myasthenia gravis and dystrophia myotonica. Acta Med. Scandinav., 116:502, 1944. 2. ASSIS, J. L. Tratamento dos casos graves de miastenia: ação do ACTH e cortisona. Considerações , a propósito de 3 casos. Arq. de Neuro-Psiquiat., 14:28, 1956. 3. BARSOUM, G. S. - The acethylcholine equivalent of nervous tissues. J. Physiol., 84:259, 1935.4. BARTON, F. E. e BRANCH, C. F. - Myasthenia.gravis: case report with necropsy. J.A.M.A., 169:204, 1937. 5. BELL, E. T. - Tumors of the thymus in myasthenia gravis. J. Nerv. a. Ment. Dis., 45:130, 1917. 6. BLALOCK, A.; MASON, M. F.; MORGAN, H. J.; RIVEN, S. S. - Myasthenia gravis and tumors of the thymic region. Ann. Surg., 110:544, 1939. 7. BOTELHO, S. Y. - Comparison of simultaneously recorded electrical and mechanical activity in myasthenia gravis patients and in partially curarized normal humans. Am. J. Med., 19:693, 1955. 8. BRAZIER, M. - Electromyographic and ergographic studies in myasthenia gravis. J. Nerv. a. Ment. Dis., 100:615, 1944. 9. BREM, J. e WECHSLER, H. F. — Myasthenia gravis associated with thymoma. Arch. Int. Med., 34:901, 1934. 10. BUSCAINO, G. A. - Panorami di Biochimica Topografica del Sistema Nervoso. Acta Neurol. Policlinico Nápoles, 1950. 11. BUTT, H. R. - Myasthenia gravis: study of post-mortem observations including demonstration of Gram positive bacteria (streptococci) in and between muscle fibers. Arch. Path., 21:27, 1936. 12. CASTLEMAN, B. e NORRIS, E. H. - Pathology of the thymus in myasthenia gravis. Medicine, 28:27, 1949. 13. CHURCHILL-DAVIDSON, H. C. e RICHARDSON, A. T. - Neuromuscular transmission in myasthenia gravis. J. Physiol., 122:252, 1953. 14. COËRS, C. - Les variations structurelles normales et pathologiques de la function neuromusculaire. Acta Neurol. et Psychiat. Belg., 55:741, 1955. 15. COËS, C. e DESMEDT, J. E. Mise en évidence d'une malformation caractéristique de la fonction neuromusculaire dans la myasthénie. Corrélations histo et physio-pathologiques. Acta Neurol. et Psychiat. Belg., 59:539, 1959. 16. COHEN, R. B.; ZACKS, S. e CASTLEMAN, B. - 
Histochemical demonstration of acetylcholinesterase in motor and plates of extraocular muscle in myasthenia and non-myasthenic subjects (Abst.). Am. J. Path., 32:639, 1956. 17. COMROE, J. H.; TODD, J.; GAMMON, G. D.; LEOPOLD, I. H.; KOELLE, G. B.; BODANSKY, O.; GILMAN, A. - The effect of di-isopropyl fluorophosphate (DFP) upon patients with myasthenia gravis. Am. J. M. Sc., 212:641, 1946. 18. CONN, J. W.; LOUIS, L. H.; JOHNSTON, M. W. - Effects of intravenous reduced glutathione (GSH) upon giycosuria and hyperglycemia induced in man by adrenocorticotropic hormone (ACTH). J. Clin. Invest., 28:775, 1949.19. DALE, H. H. - Some chemical factors in the control of circulation. Lancet, 1: 1179, 1929. 20. DALE, H. H. - Progress in autopharmacology. Bull. Johns Hopkins Hosp., 53:297, 1933. 21. DESMEDT, J. E. - Premiers résultats thérapeutiques avec le Mytelaze (Mysuran, WIN-8077) dans la myasthénie. Acta Neurol. et Psychiat. Belg., 57:94, 1957. 22. DEULOFEU, V. e MARENZI, A. D. - Química Biológica. Editora Guanabara, Rio de Janeiro, 1955. 23. DITTLER, L. E. - Remission in a case of myasthenia gravis following the use of ACTH. Nerv. State J. M., 52:1565, 1952. 24. DOUGHERTY, T. F. e WHITE, A. - Effect of pituitary adrenotropic hormone on lymphoid tissue. Prac. Soc. Exper. Biol, a. Med., 53:132, 1943.25. EATON, L. M. e CLAGETT, O. T. - Thymectomy in treatment of myasthenia gravis. J.A.M.A., 142:963, 1950. 26. EATON, L. M. e CLAGETT, O. T. - Present status of thymectomy in treatment of myasthenia gravis. Am. J. Med., 19:703, 1955.27. FORSHAM, P. A.; THORN, G. W.; PRUNTY, F. T. C. e HILLS, A. G. - Clinical studies with pituitary adrenocorticotropin. J. Clin. Endocrinol., 8:15, 1948.28. GAMMON, G. D. - Symposium on Myasthenia gravis. Am. J. Med., 19:655, 1955. 29. GIORDANO, A. S. e HAYMOND, J. L. - Myasthenia gravis: a report of two cases with necropsy findings. Am. J. Clin. Path., 14:253, 1944. 30. GROB, D. Discussion of WIN-8077 in the treatment of sixty myasthenia gravis. Use of $N^{\prime}, N^{1}$-bis(2-diethylaminoethyl)-oxamide-bis-2-chlorobenzylchloride in fifty patients. J.A.M.A., 158:625, 1955. 31. GROB, D. e HARVEY, A. M. - Observations on the effects of tetraethylpyrorophosphate (TEPP) in man, and its use in the treatment of myasthenia gravis. Bull. Johns Hopkins Hosp., 84:532, 1949. 32. GROB, D. e HARVEY, A. M. - Effect of adrenocorticotropic hormone (ACTH) and cortisone administration in patients with myasthenia gravis and report of on set of myasthenia gravis during prolonge cortisone administration. Bull. John Hopkins Hosp., 91:124, 1952. 33. GROB, D. e JOHNS, R. J. - Use of oximes in the treatment of intoxication during prolonge cortisone administration. Bull. Johns Hopkins Hosp., 91:124, 1952. by anticholinesterase compounds in patients with myasthenia gravis. Am. J. Med., 24:512, 1958. 34. GROB, D. e JOHNS, R. J. - Treatment of anticholinesterase intoxication with oximes. J.A.M.A., 166: 1855, 1958. 35. GROB, D.; JOHNS, J. e HARVEY, A. M. - Alterations in neuromuscular transmission in myasthenia gravis as determined by studies of drug action. Am. J. Med., 19:684, 1955. 36. HARVEY, A. M. e LILIENTHAL, J. L. - Observation on the nature of myasthenia gravis. The intra-arterial injection of acetylcholine, prostigmine and adrenaline. Bull. Johns Hopkins Hosp., 69:566, 1941. 37. HARVEY, A. M.; LILIENTHAL, J. L. e TALBOT, S. A. - Observations on the nature of myasthenia gravis. The phenomena of facilitation and depression of neuromuscular transmission. Bull. Johns Hopkins Hosp., 69:547, 1941. 38. HARVEY, A. M. e MASLAND, R. L. - The electromyogram in myasthenia gravis. Bull. Johns Hopkins Hosp., 69:1, 1941. 39. INGLE, D. J. - Effect of endocrine glands on normal muscle. Work, 19:724, 1955.40. JONES, M. S. e STADIE, W. C. - Choline esterase content of muscle of myasthenia gravis and serum of 4 other groups of clinical conditions. Quart. J. Exper. Physiol., 29:63, 1939. 41. KANE, C. A. - The effect of certain endocrine glands on myasthenia gravis. Am. J. Med., 19:729, 1955. 42. KANE, C. A. e WEED, L. - Myasthenia gravis associated with adrenocortical insufficiency. New England J. Med., 243:939, 1950. 43. KEYNES, G. - Surgery of the thymus gland; second (and third) thoughts. Lancet, 1:1197, 1954. 44. KOELLE, G. B. - Histochemical localization of cholinesterase. J. Pharmacol. a. Exper. Therap., 103:153, 1951.45. KOELLE, G. B. - Structure of the motor end plate. Am. J. Med., 19:661, 1955. 46. LINDOLEY, D. B. - Myographic and electromyographic studies of myasthenia 
gravis. Brain, 58:470, 1935. 47. LOEWI, O. - On problems connected with the principle of humoral transmission of nervous impulses. Proc. Roy. Soc. Med., 118: 229, 1935. 48. MARINESCO, G. - Contribution à l'étude de la myasthénie grave pseudoparalytique. Semaine méd., 28:421, 1908. 49. MILLIKAN, C. H. e EATON, L. M. - Clinical evaluation of ACTH and cortisone in myasthenia gravis. Neurology, 1:145, 1951. 50. NEUZIL, E. e TAYEAU, F. - Etude de l'influence des facteurs biochimiques, métaboliques et endocriniens sur l'électroencéphalogramme. Introduction aux repports. Révue Neurol., 100(4):249, 1959. 51. NORRIS, E. H. The thymoma and thymic hyperplasia in myasthenia gravis, with observations on the general pathology. Am. J. Cancer, 27:421, 1936. 52. O'LEARY, P. A. e WAISMAN, M. - Dermatomyositis: a study of 40 cases. Arch. Dermat. a. Syph., 41: 1001, 1940. 53. OSSERMAN, K. E. - Myasthenia Gravis. Grune \& Stratton, Nova York e Londres, 1958. 54. OSSERMANN, K. E. e KAPLAN, L. I. - Rapid diagnostic test for myasthenia gravis increased muscle strenght, without fasciculations, after intravenous administration of edrophonium (Tensilon) chloride. J.A.M.A., 150: 265, 1952. 55. OSSERMANN, K. E. e KAPLAN, L. I. - Studies in myasthenia gravis. Present status of therapy with octamethyl Phyrophosphoramide (OMPA). Ann. Int. Med., 41:108, 1954. 56. OSSERMANN. K. E. e TENG, P. -- Studies in myasthenia gravis: A rapid diagnostic test. Further progress with Edrophonium (Tensilon) chloride. J.A.M.A.. 160:153, 1956. 57. OSSERMANN, K. E.; TENG, P. e KAPLAN, L. I. - Studies in myasthenia gravis: Preliminary reports on therapy with mestinon bromide. J.A.M.A., 155:961, 1954. 58. PATEISKY, K. - Meeting of Society of Physicians of Vienna, Feb. 1955. J.A.M.A., 158:1187, $1955 . \quad 59$, RAMOS, A. O. - Ação curarizante do plasma e do extrato de timo de paciente portador de miastenia grave. Rev. Brasil. Biol., 18:93, 1958. 60. RANDT, C. 'T. - Myasthenia gravis. Med. Clin. N. Amer., 37:535, 1953. 61. RAVIN, H. A.; ZAEKS, S. I. e SELIGMAN, A. M. - Histochemical localization of acetylcholinesterase in nervous tissue. J. Pharmacol. Exper. Therap,, 107:37, 1953. 62. RIDER, J. A.; SHULMAN, S.; RICHTER, R. B.; MOELHER, H. C. e DUBOIS, K. P. - Treatment of myasthenia gravis with octamethyl-pyrophosphoramide. J.A.M.A., 145:967, 1951. 63. RITTER, J. A. e EPSTEIN, N. - Myasthenia gravis. Some observations on the effects of various therapeutic agents, including thymectomy and ACTH in nine year old child. Am. J. Med. Sc., 220:66, 1950. 64. ROTTINS, A.; POPPITI, R. e RAO, J. Myocardial lesions in myasthenia gravis. Arch. Path., 34:557, 1942. 65. ROWLAND, L. P.; HOEFER, P. F. A.; ARANOW, H. e MERRITT, H. H. - Fatalities in myasthenia gravis. Neurology, 6:307, 1956. 66. RUSSELL, D. - Histological changes in the striped muscles in myasthenia gravis. J. Path. a. Bact., 65:279, 1953.67. SCHLEZINGER, N. S. - Present status of theràpy in myasthenia gravis. J.A.M.A., 148:508, 1952. 68. SCHLEZINGER, N. S. - Pregnancy in myasthenia gravis and neonatal myasthenia gravis. Am. J. Med., 19:718, 1955. 69. SCHWAB, R. S.; MARSHALL, C. K. e TIMBERLAKE, W. - WIN-8077 in the treatment of myasthenia gravis. Use of N,N'-bis-(2-diethylaminoethyl)-oxamide-bis-2-chlorobenzylchloride in fifty patients. J.A.M.A., 158:625, 1955. 70. SCHWARTZ, H. - Discussion of Wilson, A. and Wilson, H. - The thymus and myasthenia gravis. Am. J. Med., 19:697, 1955. 71. SELYE, H| - Stress. Acta, Inc. Medical Publishers. Montreal, 1950. 72. SHULMAN, S.; RIDER, J. A. e RICHTER, R. B. - Use of octamethylpyrophosphoramide in the treatment of myasthenia gravis. Further observations. J.A.M.A., 152:1707, 1953. 73. SHY, G. M.; BRENDLER, S.; RABINOVITCH, R. e McEACHERN, D. - Effects of cortisone in certain neuromuscular disorder. J.A.M.A., 144:1353, 1950. 74. SIMPSON, J. A. -- An evaluation of thymectomy in myasthenia gravis. Brain, 81:112, 1958. 75. SIMPSON, M. E.; LI, C. H.; REINHARDT, W. O. e EVANS, H. M. - Similarity of response of the thymus and lymph nodes to administrations of adrenocorticotropic hormone in rat. Proc. Soc. Exper. Biol. a. Med., 54:135, 1943. 76. SLOAN Jr., H. E. - The thymus in myasthenia gravis with observations on the normal anatomy and histology of the thymus. Surgery, 13:154, 1943. 77. SOFFER, I. J. - Effects of adrenocorticotrophic hormone (ACTH) in myasthenia gravis with tumor of thymus. J. Mt. Sinai Hosp., 15:73, 1948.78. TALBOTT, J. H. e FERRANDIS, R. M. - Enfermedades del Colágeno. Editorial 
Cientifico-Médica, Barcelona, 1957. 79. TETHER, J. E. - Mestinon in myasthenia gravis: Preliminary report. Dis. Nerv. System, 15:227, 1954. 80. TETHER, J. E. Treatment of myasthenia gravis with mestinon bromide. J.A.M.A., 160:156, 9156. 81. THORN, G. W.; PRUNTY, F. T. G. e FORSCHAM, P. A. - Metabolic changes following the administration of pituitary adrenocorticotropic hormone (ACTH) in man. J. Clin. Endocrinol., 7:459, 1947. 82. TORDA, C. e WOLFF, H. G. - Effect of pituitary adrenotropic hormone on lymphoid tissue. Proc. Soc. Exper. Biol. a. Med., 53:132, 1943. 83. TORDA, C. e WOLFF, H. G. - Effect of adrenocorticotrophic hormone of pituitary gland on ability of tissue to synthesize acethylcholine. Proc. Exper. Biol. a. Med., 57:137, 1944. 84. TORDA, C. e WOLFF, H. G. - Effect of blood serum from patients with myasthenia gravis on the synthesis of acethylcholine in vitro. J. Clin. Invest., 23:649, 1944. 85. TORDA, C. e WOLFF, H. G. - Effect of ether extracts of thymus and pancreas on synthesis of acetylcholine. Proc. Soc. Exper. Biol. a. Med., 57:69, 1944. 86. TORDA, C. e WOLFF, H. G. - Effect of steroid substances on synthesis of acetylcholine. Proc. Soc. Exper. Biol. a. Med., 57:327, 1944. 87. TORDA, C. e WOLFF, H. G. - Decomposition products of nucleoproteins and related substances and muscle sensitivity to acethylcholine and potassium. Proc. Soc. Exper. Med., 58:29, 1945. 88. TORDA, C. e WOLFF, H. G. Acetylcholine synthesis. Science, 103:645, 1946. 89. TORDA, C. e WOLFF, H. G. - Effect of organ extracts and their fractions on acetylcholine synthesis. Am. J. Physiol., 148:417, 1947. 90. TORDA, C. e WOLFF, H. G. - Effect of adrenocorticotrophic hormone on neuro-muscular function in patients with myasthenia gravis. Proc. Soc. Exper. Biol. a. Med., 71:432, 1949. 91. TORDA, C. e WOLFF, H. G. - Effects of adrenocorticotrophic hormone on neuromuscular function in patients with myasthenia gravis. J. Clin. Invest., 28:1228, 1949. 92. TORDA, C. e WOLFF, H. G. - Effect of hipophysectomy on neuromuscular function. Am. J. Physiol., 156:274, 1949. 93. TORDA, C. e WOLFF, H. G. - Effect of administration of the adrenocorticotrophic, hormone (ACTH) on patients with myasthenia gravis. Arch. Neurol, a. Psychiat., 66:163, 1951. 94. TORDA, C. e WOLFF, H. G. - Effects of hipophysectomy and adrenocorticotrophic hormone on neuromuscular function and acetylcholine synthesis. Am. J. Physiol., 161:534, 1950. 95. Van MAANEN, E. F. - Neuromuscular blocking agents. Am. J. Med., 19:669, 1955. 96. VIETS, H. R. e SCHWAB, R. S. - Prostigmin in the diagnosis of myasthenia gravis. New England J. Med., 213:1280, 1935. 97. WALKER, M. B. - Treatment of myasthenia gravis with physostigmine. Lancet, 1:1200, 1934. 98. WALKER, M. B. - Case showing the effect of prostigmin on myasthenia gravis. Proc. Roy. Soc. Med., 28: 759, 1935. 99. WESTERBERG, M. R. - Clinical evaluation of Ambenonium (mysuran chloride). Arch. Neurol. a. Psychiat., 75:91, 1956. 100. WESTERBERG, M. R. e LURES, J. T. - The clinical use of hexaecthyltetraphosphate in myasthenia gravis. Univ. Hosp. Bull. Ann Arbor, 14:15, 1948. 101. WESTERBERG, M. R.; MAGEE, K. R. e SHIDEMAN, E. F. - Effect of 3-hydroxyphenyldimethylamonium chloride (Tensilon) in myasthenia gravis. Michigan M. Bull., 17:311, 1950.102. WESTERBERG, M. R.; MAGEE, K. R. e SHIDEMAN, E. F. - Effect of Tensilon in myasthenia gravis. Neurology, 3:302, 1953. 103. WESTERBERG, M. R. e MAGEE, K. R. - Mestinon in the treatment of myasthenia gravis. Neurology, 4:762, 1954. 104. WILSON, A.; OBRIST, A. R. e WILSON, H. - Some effects of extracts of thymus glands removed from patients with myasthenia gravis. Lancet, 2:368, 1953. 105. WILSON, A. e WILSON, H. - The thymus and myasthenia gravis. Am. J. Med., 19:697, 1955. 106. ZONDEK, H. e TICHO, A. - Myasthenia gravis and malignant exophthalmos. Lancet, 2:1018, 1951.

Clínica Neurológica - Hospital das Clinicas da Fac. Med. da Univ. de São Paulo - Caixa Postal 3461 - São Paulo, Brasil. 